\title{
PEMANFAATAN LIMBAH TAHU \\ SEBAGAI UPAYA MENINGKATKAN PEREKONOMIAN MASYARAKAT DESA BRINGINAN, KECAMATAN JAMBON, PONOROGO
}

\author{
Ayunda Riska Puspita \\ Fakultas Tarbiyah dan Ilmu Keguruan, IAIN Ponorogo \\ Email: puspita@iainponorogo.ac.id
}

\begin{abstract}
ABSTRAK
Setiap daerah pasti memiliki aset atau potensi yang dapat dikembangkan, termasuk Desa Bringinan, Jambon, Ponorogo. Salah satu aset yang dimiliki oleh masyarakat Desa Bringinan adalah home indutry tabu yang dalam pengelolaannya menghasilkan limbah padat dan cair. Pengelolaan limbah, khususnya limbah padat (ampas tabu), di desa ini belum maksimal. Ampas tabu banya digunakan sebagai pakan ternak dengan nilai jual yang sangat rendah. Jadi, kasiat ampas tahu tidak dimanfaatkan dengan baik. Padahal gizi ampas tahu ternyata masih terbilang banyak dan cocok untuk diolah untuk menjadi bahan makanan yang beragam variasinya. Pendampingan yang dilakukan dalam kegiatan pengabdian kepada masyrakat ini adalah pengolahan ampas tahu menjadi keripik ampas tabu yang bernilai jual tinggi. Pendekatan yang digunakan adalah pendekatan Asset Based Comunity-Driven Development (ABCD) dengan menggali aset yang dimiliki masyarakat Desa Bringinan. Pendampingan dilakukan mulai produksi, pengemasan, hingga pemasaran. Pendampingan dilakukan secara berkelanjutan sampai home industry keripik ampas tabu benar-benar matang. Pendampingan pengelolaan ampas tabu ini bertujuan untuk mengurangi jumlah TKW di Desa Bringinan dan meningkatkan perekonomian ibu-ibu PKK Desa Bringinan.
\end{abstract}

Kata kunci: Limbah Tabu, Keripik Ampas Tabu, Perekonomian Desa Bringinan

\begin{abstract}
Each region must have assets or potential that can be developed, including Bringin Village, Jambon, Ponorogo. One of the assets owned by the people of Bringin Village is the tofu home industry which in its management produces solid and liquid waste. Waste management, especially solid waste (tofu dregs), in this village is not optimal. Tofu dregs are only used as animal feed with a very low selling value. So, the benefits of tofu dregs are not used properly. In fact, the nutrition of tofu dregs is still quite large and suitable for processing into various variations of food. The assistance carried out in this community service activity is processing tofu dregs into tofu dregs chips
\end{abstract}


which have high selling value. The approach used is the Asset Based Community-Driven Development (ABCD) approach by exploring the assets owned by the people of Bringin Village. Assistance is carried out from production, packaging to marketing. Assistance is carried out continuously until the tofu chips home industry is fully cooked. The tofu dregs management assistance aims to reduce the number of TKW in Bringin Village and improve the economy of PKK women in Bringin Village.

Keywords:Tofu Waste, Tofu Dregs Chips, The Economy of Bringinan Village

\section{PENDAHULUAN}

Bringinan merupakan sebuah desa yang terletak di kecamatan Jambon, kabupaten Ponorogo, Provinsi Jawa Timur dengan luas wilayah 138,77 hektar. Wilayah ini dibagi menjadi tiga dusun, yaitu Dusun Dondong, Dusun Ngasem, dan Dusun Kedung. Mayoritas masyarakat Desa Bringinan bermata pencaharian sebagai petani, yakni sebanyak 441 orang, buruh tani sebanyak 250 orang, PNS sebanyak 3 orang, TNI 1 orang, dan TKI/ eks TKI sebanyak 341 orang.

Kondisi ekonomi masyarakat sekitar dapat dikatakan sebagai kalangan menengah ke bawah. Mayoritas pekerjaan mereka adalah sebagai petani karena kondisi geografis wilayah desa tersebut berupa tanah persawahan. Akan tetapi, karena terbatasnya pengairan di persawahan, pada musim kemarau banyak sawah yang tidak ditanami atau istilahnya disebut bero.

Untuk menciptakan perekonomian penduduk yang lebih baik salah satunya dibutuhkan ciri khas suatu desa yang dapat menjadi identitas desa tersebut. Perekonimian yang berasas inovasi pembangunan juga didukung dengan adanya dana desa sebagai sumber biaya pembangunan yang mandiri. Bahkan penggerakan unit perekenomian terkecil di Desa Bringinan terdapat Bumdesa Margo Mulyo atau lebih terkenal Bringinan Mart yang secara resmi dibuka oleh dan untuk masyarakat. Bringinan Mart mempunyai peran penting dalam peningkatan perekonomian masyarakat mulai dari koperasi simpan pinjam, menampung produk UKM, sampai memberikan wadah tenaga kerja lokal untuk mencipatakan sebuah produk dan sebagai jembatan kesuksesan suatu industri. Maka dari itu pada aspek keberhasilan suatu desa dan masyarakat yang sudah mulai dikembangkan, harus ada terobosan baru untuk membuat sebuah produk yang nantinya diharapkan dapat menjadi ikon desa dan peluang tersebut terdapat pada pengolahan ampas dari pengolahan tahu yang ada di Desa Bringinan. Sebelumnya di Desa Bringinan sudah ada pabrik tahu yang pemanfaan limbahnya kurang begitu maksimal.

Limbah tahu di Kabupaten Ponorogo, khususnya di Desa Bringinan, belum dimanfaatkan dengan maksimal bahkan tidak dimanfaatkan sama sekali. Limbah tahu, khususnya limbah padat, hanya digunakan untuk pakan ternak dan tempe gembos dengan harga jual yang rendah. Padahal dari kandungan gizi dalam ampas tahu ternyata masih terbilang banyak dan cocok untuk diolah menjadi bahan makanan yang beragam variasinya. Maka kemudian 
kami berkoordinasi dengan desa untuk memanfaatkan ampas tahu menjadi keripik dan dijadikan usaha desa dengan nilai jual yang lumayan tinggi dibandingkan dengan pakan ternak. Dengan harga yang terjangkau dan proses yang sangat mudah, pengolahan ampas tahu menjadi keripik sangat cocok untuk merintis usaha dengan mengolah bahan yang jarang dimanfaatkan bias menjadi produk unggulan.

Pengolahan kripik ampas tahu dapat dilakukan dengan dua cara, yaitu memanfaatkan limbah padat sebagai bahan tambahan dan menggunakan tepung ampas tahu sebagai bahan utama. ${ }^{1}$ Dalam kegiatan ini dipilih proses yang pertama yakni memanfaatkan limbah padat ampas tahu karena cukup dilakukan satu kali produksi. Berbeda dengan langkah kedua yang melewati dua proses. Untuk pembuatan tepung ampas tahu bisa dilakukan pada kegiatan lain yang mungkin sasarannya bukan lagi ibu-ibu PKK, bisa pemuda/i di Desa Bringinan.

Pada saat ini kripik ampas tahu belum terlalu populer di kalangan masyarakat, khususnya di Kabupaten Ponorogo, dibandingkan dengan makanan kekinian. Maka tim Kuliah Pengabdian Masarakat IAIN Ponorogo, menggagas sebuah ide dengan memanfaatkan ampas tahu untuk dibuat kripik. Kripik ampas tahu tidak hanya dikonsumsi sebagai makanan ringan tetapi juga memiliki beberapa kandungan gizi sebagaimana ditunjukkan dalam table di bawah ini.

Tabel 1. Kandungan Gizi dalam Ampas Tahu

\begin{tabular}{|l|l|l|}
\hline No & Unsur Gizi & Ampas Tahu/100 gram \\
\hline 1. & Energi (kal) & 393 \\
\hline 2. & Air $(\mathrm{g})$ & 4,9 \\
\hline 3. & Protein $(\mathrm{g})$ & 17,4 \\
\hline 4. & Lemak $(\mathrm{g})$ & 5,9 \\
\hline 5. & Karbohidrat $(\mathrm{g})$ & 67,5 \\
\hline 6. & Mineral $(\mathrm{g})$ & 4,3 \\
\hline 7. & Kalsium $(\mathrm{g})$ & 19 \\
\hline 8. & Fosfor $(\mathrm{g})$ & 29 \\
\hline 9. & Zat besi $(\mathrm{mg})$ & 4 \\
\hline 10. & Vitamin B $(\mathrm{mg})$ & 0,2 \\
\hline $\begin{array}{l}\text { Sumber data }: \text { Daftar Analisis Bahan Makanan Fak. Kedokteran } \\
\text { UI }{ }^{1}\end{array}$ \\
\hline
\end{tabular}

1 Rizqie Auliana, "Pengolahan Limbah Tahu menjadi Berbagai Produk Makanan" (Pertemuan, Pertemuan Dasa Wisma, Dusun Ngasem Sindumartani, Kecamatan Ngemplak, Sleman, Yogyakarta, Oktober 2017), 17. 
Pembentukan home industry juga dapat mengurangi jumlah TKW yang berangkat ke luar negeri. Dengan adanya home industry yang mandiri dikelola sendiri oleh masyarakat, khususnya ibu-ibu PKK maka akan tercipta lapangan pekerjaan baru. Semakin besar home industry tersebut maka akan semakin banyak menyerap tenaga kerja. Jadi ini merupakan salah satu upaya mengurangi jumlah TKW yang berangkat ke luar negeri dan juga meminimalkan resiko permasalahan yang timbul di lingkungan keluarga karena berangkatnya TKW ke luar negeri tersebut.

Kegiatan pengabdian yang serupa, yaitu tentang pengolahan limbah ampas tahu, sudah beberapa kali dilakukan. Namun, di Desa Bringinan ini adalah hal yang baru yang sebelumnya belum pernah ada. Berikut beberapa kegiatan dan tulisan tentang pemanfaatan limbah tahu. Pertama, artikel pengabdian masyarakat yang ditulis oleh Eta Yuni Lestari, Mike Meida Diningrum, dan Lukman Ibnu Haqiqi pada tahun 2019. Judul artikel pengabdian yang ditulis oleh Eta Yuni Lestari, dkk. adalah Pengembangan Nilai Tambah Ampas Tahu Bernilai Ekonomi melalui Pemberdayaan Masyarakat Desa Dadirejo Pati. Berdasarkan hasil pengabdian yang dilakukan oleh Eta Yuni Lestari, dkk. diketahui bahwa tidak hanya tahu yang dapat diolah menjadi varian makanan yang enak dan bergizi, tetapi ampas tahu dapat dimanfaatkan menjadi varian makanan, seperti donat kerupuk dan brownis. Pemanfaatan ampas tahu diharapkan memiliki nilai ekonomi yang lebih tinggi dan dapat meningkatkan upaya pemberdayaan masyarakat sehingga dapat mempercepat pembangunan desa, sekaligus sebagai dukungan pemerintah dalam pembangunan Indonesia mulai dari pinggiran yaitu desa. ${ }^{2}$ Kedua, artikel pengabdian yang ditulis oleh Merkuria Karyantina dan Kapti Rahayu K. tahun 2017. Artikel tersebut berjudul Pelatiban Pembuatan Stik dan Kerupuk Ampas Tahu di Perumnas Mojosongo. Dalam artikel masih kurang maksimal, hanya diolah sebagai tempe gembos. Manfaat Pelatihan Pembuatan aneka olahan ampas tahu bagi warga adalah diharapkan mampu meningkatkan keterampilan para anggota dalam bidang pengolahan pangan, terutama dalam hal pembuatan olahan ampas tahu, sehingga mampu memberikan tambahan penghasilan bagi keluarga. Olahan ampas tahu dapat berupa stik, kerupuk, rengginan, kue kering, dan lain-lain. ${ }^{3}$ _ Persamaan artikel pengabdian ini dengan artikel sebelumnya adalah sama-sama pengolahan limbah ampas tahu untuk untuk meningkatkan harga jual. Namun, pengabdian ini bertempat di Desa Bringinan, Jambon, Ponorogo yang memang sebelumnya belum pernah ada pelatihan pengolahan ampas tahu menjadi bahan makanan yang memiliki nilai jual tinggi. Selain itu, dalam pengabdian ini, masyarakat tidak hanya memberdayakan pengolahan limbah tahu, tapi juga memberdayakan aset desa untuk

$2 \quad$ Eta Yuni Lestari, Mike Meida Diningrum, dan Lukman Ibnu Haqiqi, "Pengembangan Nilai Tambah Ampas Tahu Bernilai Ekonomi melalui Pemberdayaan Masyarakat Desa Dadirejo Pati,” ABDIMAS: Jurnal Pengabdian Masyarakat, 23, no. 2 (2019): 175-81.

3 Merkuria Karyantina dan Kapti Rahayu K., "Pelatihan Pembuatan Stik dan Kerupuk Ampas Tahu di Perumnas Mojosongo," ADIWIDYA, 1, no. 1 (November 2017): 42-50. 
pemasaran, seperti BUMDES.

Berdasarkan latar belakang tersebut, maka dalam kegiatan pengabdian kepada masyarakat ini akan dilaksanakan pendampingan kepada masyarakat untuk membangun bome industry. Pendampingan dilakukan berdasarkan aset dan potensi yang dimiliki oleh masyarakat Desa Bringinan. Pendampingan dilakukan menggunakan metode Asset Based Community Development (ABCD) seperti yang dijelaskan pada bagian selanjutnya.

\section{METODE}

Pelaksanaan pengabdian kepada masyarakat ini menggunakan metode Asset Based Community Development (ABCD) yang mengutamakan pemanfaatan aset dan potensi yang ada di sekitar dan dimiliki masyarakat. Metode ABCD betujuan menggali aset yang dimiliki oleh suatu wilayah. Masyarakat merupakan aset yang berharga bagi sebuah desa karena aset tidak melulu benda. Beragam komunitas masyarakat di sebuah desa dapat digabungkan dengan melihat keterampilan atau potensi yang ada pada setiap masyarakat. Keterampilan dari setiap masyarakat dijadikan satu dalam wadah kelompok ibu PKK, misalnya. Ibu-ibu PKK tersebut juga termasuk salah satu aset yang bisa dikembangkan.

Adanya home industry dapat menjadi salah satu indikator kemajuan dalam masyarakat. Home industry dapat menjadi wadah untuk mengembangkan desa dan meningkatkan perekonomian. Metode ABCD menuntut partisipasi aktif masyarakat sehingga bisa mengetahui perubahan yang diinginkan dan bisa melanjutkan kedepannya. Masyarakat juga bisa mengontrol pembangunan home industry-nya. Masyarakat juga ikut serta sebagai pelaksana pengembangan home industry dengan dampingan pihak-pihak yang terkait.

Dalam Metode ABCD terdapat lima langkah kunci untuk melakukan proses penelitian pengabdian diantaranya sebagai berikut ${ }^{4}$ :

\section{Discovery (Menemukan)}

Discovery merupakan proses menemukan kembali kesuksesan dilakukan lewat proses percakapan atau wawancara dan harus menjadi penemuan personal tentang apa yang menjadi kontribusi individu yang memberi hidup pada sebuah kegiatan atau usaha. Pada tahap ini mulai digali aset apa yang terdapat di Desa Bringinan. Dalam persfektif ABCD, aset adalah sesuatu yang sangat berpotensi untuk dikembangkan. Fungsi aset tidak hanya sebatas modal sosial saja tetapi juga sebagai embrio perubahan sosial. Aset juga bisa menjadi jembatan untuk membangun relasi dengan pihak luar. Di sini komunitas dibentuk sensitif dan peka terhadap keberadaan aset yang ada di sekitar mereka. Dengan keikutsertaan masyarakat itu

\footnotetext{
4 Lembaga Penelitian dan Pengabdian kepada Masyarakat (LPPM) IAIN Ponorogo, Panduan KPM ABCD LAIN Ponorogo (Ponorogo: Lembaga Penelitian dan Pengabdian kepada Masyarakat (LPPM) IAIN Ponorogo, 2019).
} 
sendiri sebagai penentu perubahan tersebut dan sekaligus menstimulasi masyarakat agar mau mewujudakan perubahan tersebut.

Penemukenalan aset ini dilakukan bersama dengan perangkat Desa Bringinan. Informasi mengenai aset yang terdapat di Desa Bringinan lebih banyak didperoleh dari pemaparan Bapak Kepala Desa Bringinan, Bapak Barno. Community map merupakan visualisasi pengetahuan dan persepsi berbasis masyarakat mendorong pertukaran informasi dan menyetarakan bagi semua masyarakat untuk berpartisipasi dalam proses yang mempengaruhi lingkungan dan hidup mereka. ${ }^{5}$ Pemetaan aset yang ditemukan di Desa Bringinan meliputi home industry tahu, perpustakaan desa, taman, beberapa komunitas, dan sebagainya.

\section{Dream (Impian)}

Pada tahap ini, setiap orang mengeksplorasi harapan dan impian mereka baik untuk diri mereka sendiri maupun untuk organisasi. Sebuah mimpi atau visi bersama terhadap masa depan yang bisa terdiri dari gambar, tindakan, kata-kata, dan foto. Dari kesekian aset yang dimiliki oleh Desa Bringinan, dipilih ampas tahu yang dijual dengan harga sangat murah. Pada kesempatan kali ini dihadirkan inovasi baru untuk meningkatkan nilai jual ampas tahu, yakni dibuat kripik ampas tahu.

\section{Design (Merancang)}

Proses di mana seluruh komunitas terlibat dalam proses belajar tentang kekuatan atau aset yang dimiliki agar bisa mulai memanfaatkannya dalam cara yang konstruktif, inklusif, dan kolaboratif untuk mencapai aspirasi dan tujuan seperti yang sudah ditetapkan sendiri. Proses merancang ini merupakan proses cara mengetahui apa yang dapat dikembangkan dari ampas tahu. Aset ini yang akan dimanfaatkan untuk memenuhi impian masyarakat Desa Bringinan, yakni membangun home industry kripik ampas tahu.

\section{Define (Menentukan)}

Tujuan dari proses pencarian atau deskripsi mengenai perubahan yang diinginkan. Pendampingan dengan masyarakat terlibat dalam sosialisasi. Sosialisasi yang akan dilaksanakan adalah sosialisasi produksi, pengemasan, dan pemasaran kripik ampas tahu. Sosialisasi ditujukan kepada ibu-ibu PKK. Sosialisasi dilakukan untuk ibu-ibu PKK yang berada di tiga dusun yang terdapat di Desa Bringinan.

Christopher Derau, "Pembaru dan Kekuatan Lokal untuk Pembangunan," Australian Community Development and Civil Society Strenghtening Scheme (ACCESS) Tahap II, Agustus 2013, 96-97. 


\section{Destiny (Lakukan)}

Serangkaian tindakan inspiratif yang mendukung proses belajar terus menerus dan inovasi tentang "apa yang akan terjadi." Hal ini merupakan fase akhir yang secara khusus fokus pada cara-cara personal dan organisasi untuk melangkah maju. Langkah yang terakhir adalah melaksanakan kegiatan yang sudah disepakati untuk memenuhi impian masyarakat dari pemanfaatan aset. Selain untuk memenuhi impian masyarakat agar berkembangnnya home industry keripik ampas tahu dari segi produksi, pengemasan, dan pemasaran.

Model pengolahan limbah tahu yang diterapkan dalam kegiatan kali ini adalah dengan memanfaatkan limbah ampas tahu agar bernilai jual yang lebih tinggi dibandingkan dengan yang sebelumnya hanya dijual seagai pakan ternak tanpa diolah. Pada model kegiatan kali ini pengolahan ampas tahu tidak hanya berhenti ketika menjadi makanan alternatif, namun dalam kegiatan ini diharapkan adanya home indutry keripik ampas tahu. Berikut disajikan model pengolahan ampas tahu dalam kegiatan ini.

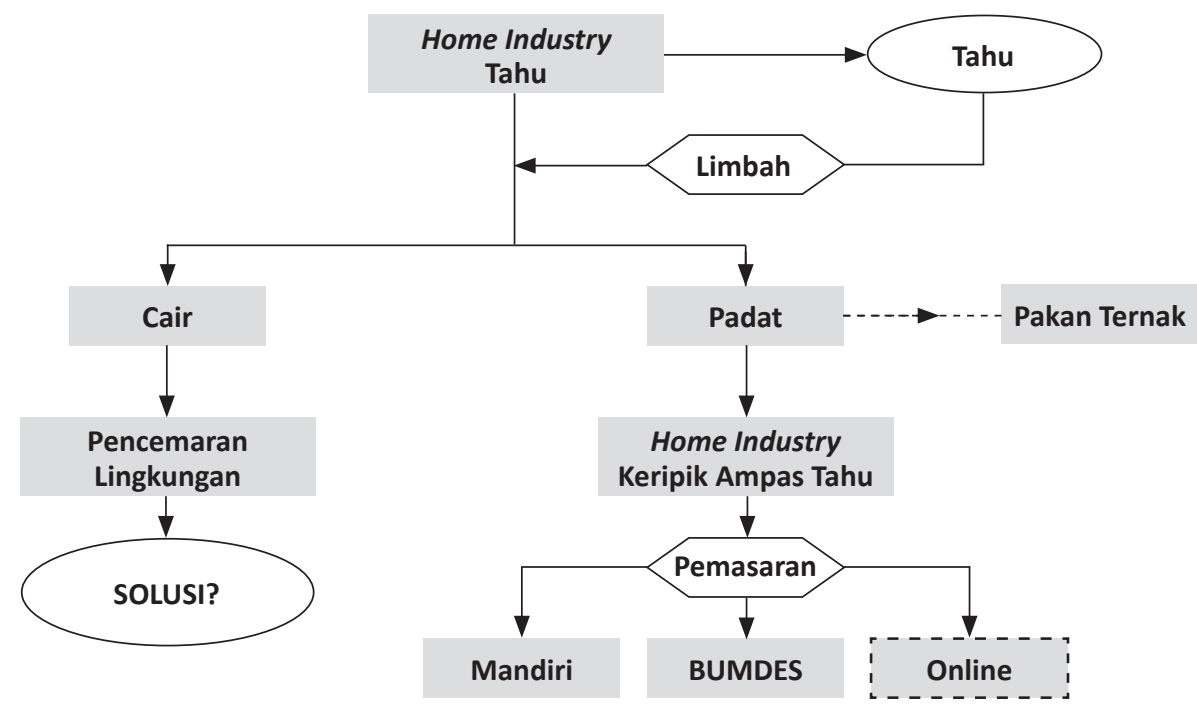

Gambar 1 Model Pengolahan Ampas Tahu

Berdasarkan diagram di atas diketahui bahwa selain fokus pada pengolahan juga fokus pada pemasaran memanfaatkan pemasaran mandiri oleh ibu-ibu PKK, BUMDES, dan secara online yang akan dijalankan oleh pemuda di Desa Bringinan.

\section{ANALISIS DAN PEMBAHASAN}

Masyarakat Desa Bringinan merupakan masyarakat yang berpotensi untuk lebih 
berkembang. Hal ini dapat terlihat dengan perkembangan masyarakat Desa Bringinan yang dulunya desa ini merupakan desa tertinggal yang kemudian meningkat menjadi desa berkembang. Status desa berkembang diperoleh Desa Bringinan ketika dipimpin oleh Lurah Barno. Berkembangnya Desa Bringinan menjadikan masyarakat Desa Bringinan harus berinovasi membangun desanya.

Untuk menciptakan inovasi-inovasi baru dalam membangun Desa Bringan, masyarakat dapat didampingi oleh perguruan tinggi sebagai salah satu perwujudan tridharma di perguruan tinggi oleh dosen, yaitu pengabdian kepada masyarakat. Salah satu pendampingan yang ditawarkan perguruan tinggi, dalam kegiatan ini dari IAIN Ponorogo, adalah dengan menawarkan solusi untuk meningkatkan nilai jual limbah tahu. Awalnya limbah ampas tahu hanya dijual sebagai pakan ternak dan tempe gembos.

Pendampingan dilakukan mulai dari pembentukan kelompok produksi di masingmasing dusun, sosialisasi produksi kripik ampas tahu, sosialisasi pengemasan produk kripik ampas tahu, monitoring dan controlling produksi dan pemasaran produk kripik ampas tahu. Pendampingan ini merukan pendampingan yang berkelanjutan dan tidak berhenti sampai pada pembuatan kripik ampas tahu saja, melainkan didampingi sampai home industry yang dijalankan oleh ibu-ibu PKK di Desa Bringinan benar-benar mapan.

Sosialisasi pengolahan limbah tahu yang berbentuk padat, yakni ampas tahu, yang bertujuan untuk membangun home industry yang baru dimulai dari penyusunan struktur organisasi pengelola home industry. Di Desa Bringinan terdapat tiga dusun, seperti yang telah disebutkan sebelumnya, sehingga di Desa Bringinan dibentuk 3 struktur kelompok produksi kripik ampas tahu. Ketiga kelompok produksi tersebut penanggung jawabnya adalah Ibu Fitri Nuryani, istri Bapak Barno, Lurah Desa Bringinan. Karena kelompok produksi ini digerakkan oleh ibu-ibu PKK, termasuk Bu Lurah, maka Bu Lurah lah yang menjadi penanggung jawab kegiatan ini. Berikut struktur kelompok produksi kripik ampas tahu.

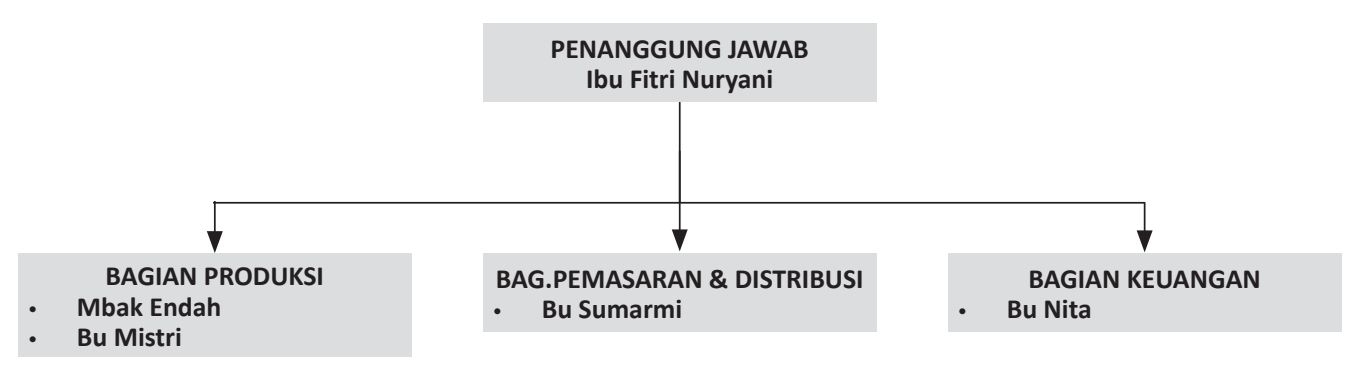

Gambar 2. Struktur Kelompok Produksi 'Ngasem' "Keripik Ampas Tahu” Rumah Produksi Endah 


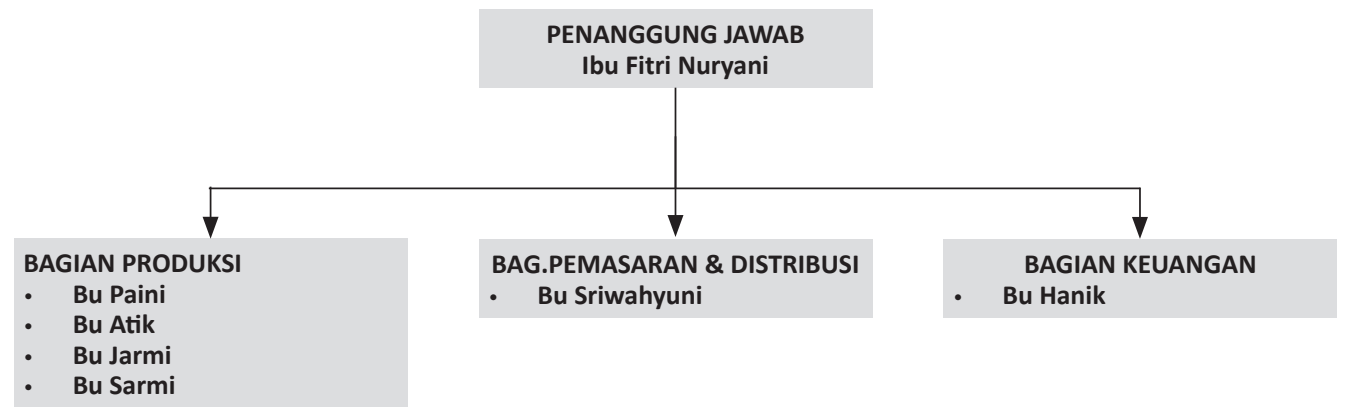

Gambar 3. Struktur Kelompok Produksi Ndondong "Keripik Ampas Tahu” Rumah Produksi Ibu Atik

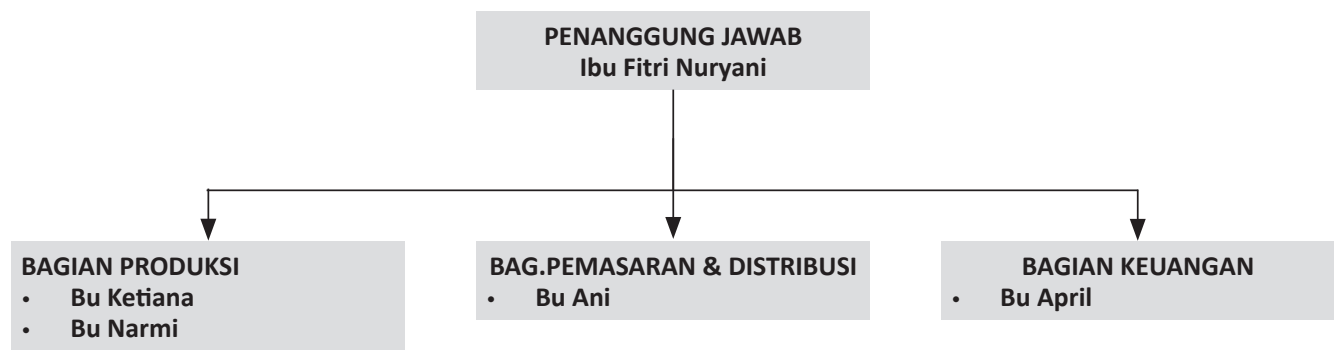

Gambar 4. Struktur kelompok produksi Kedung "Keripik Ampas Tahu” Rumah Produksi Ibu Ketiana

Ketiga kelompok produksi kripik ampas tahu tersebut berada di dusun yang berbeda. Pembentukan ketiga kelompok ini diharapkan agar tidak hanya satu dusun saja yang aktif memproduksi kripik ampas tahu. Dengan adanya ketiga kelompok produksi tersebut diharapkan akan ada banyak home industry dan tercipta lapangan pekerjaan untuk ib-ibu PKK di Desa Bringinan.

Selesai pembentukan struktur kelompok produksi di Desa Bringinan, kegiatan selanjutnya adalah sosialisasi produksi kripik ampas tahu. Bahan-bahan yang dibutuhkan dalam produksi ampas tahu adalah sebagai berikut. 
1. Ampas tahu

2. Tepung tapioca

3. Soda kue

4. Garam

5. Penyedap rasa

6. Ketumbar

7. Bawang putih

8. Merica

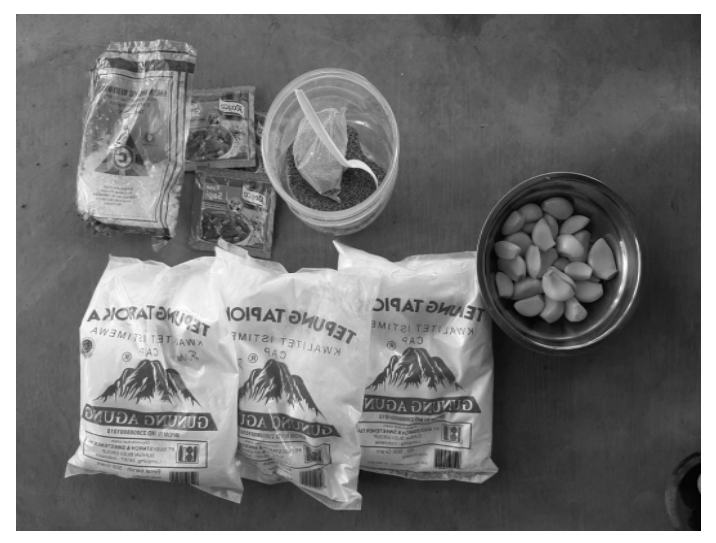

Gambar 5. Bahan-bahan Keripik Ampas Tahu

Selain disosialisasikan tentang bahan-bahan untuk memproduksi kripik ampas tahu, selanjutnya disosialisakian langkah-langkah memproduksi kripik ampas tahu. Langkahlangkah produksi kripik ampas tahu sebagai berikut.

1. Siapkan ampas tahu

2. Masukkan bumbu yang telah dihaluskan

3. Lalu, aduk merata

4. Kemudian, tambahkan tepung tapioka sedikit demi sedikit

5. Masukkan soda kue

6. Aduk merata hingga adonan kalis

7. Buat adonan menjadi bentuk lonjong

8. Kukus adonan selama kurang lebih 25-30 menit

9. Dinginkan adonan yang sudah dikukus

10. Lalu adonan siap untuk dicetak

11. Lalu jemur adonan yang sudah dicetak

Untuk menarik pelanggan, disarankan kepada masyarakat untuk membuat cita rasa yang bervariasi mulai dari original dan balado. Sasaran konsumen kripik balado ini adalah semua umur dengan berbagai macam selera. Sehingga untuk menarik konsumen harus disediakan berbagai macam pilihan rasa.

Dalam pengembangan usaha produksi kripik ampas tahu modal yang digunakan lumayan terjangkau dengan peningkatan nilai jual yang bisa dikatakan baik jika dibandingkan dengan nilai jual ampas tanpa diolah. Berikut kalkulasi dana yang dibutuhkan dalam satu kali produksi keripik ampas tahu. 
Tabel 2. Estimasi Harga Produksi Keripik Ampas Tahu

\begin{tabular}{|l|l|}
\hline \multicolumn{1}{|c|}{ BAHAN-BAHAN } & HARGA \\
\hline Ampas Tahu 5 kg & $\mathrm{Rp} 6000$ \\
\hline Royco 4 bungkus & $\mathrm{Rp} 2000$ \\
\hline Bawang 24 siung & $\mathrm{Rp} 7000$ \\
\hline Garam+Tumbar+Merica & $\mathrm{Rp} 2000$ \\
\hline Tepung Tapioka & $\mathrm{Rp} 15000$ \\
\hline Minyak Goreng & $\mathrm{Rp} 6000$ \\
\hline Balado & $\mathrm{Rp} 2000$ \\
\hline Stiker+Plastik @1000 & $\mathrm{Rp} 60.000$ \\
\hline Lain-lain & $\mathrm{Rp} 15.000$ \\
\hline Total Pengeluaran Produksi & $\mathrm{Rp} 115.000$ \\
\hline
\end{tabular}

Dengan modal Rp 115.000,00 untuk sekali produksi dengan bahan utama $5 \mathrm{~kg}$ ampas tahu dapat dijual dengan total harga Rp 180.000,00. Laba bersih yang diperoleh dari sekali proses produksi keripik ampas tahu adalah Rp 65.000,00. Berikut kalkulasi perolehan laba hasil satu kali produksi.

Tabel 3. Estimasi Pendapatan Hasil Produksi Keripik Ampas Tahu

\begin{tabular}{|l|ll|}
\hline \multicolumn{2}{|l|}{ Satu Kali Produksi (Diperkirakan Menjadi 60 Bungkus) } \\
\hline Total Keseluruhan Produksi & $:$ & Rp. 115.000 \\
\hline Harga Bersih Per Bungkus & $:$ & Rp. $115.000: 60 /$ Bks $=$ Rp. 2000 \\
\hline Harga Jual & $:$ & Rp. 3000 \\
\hline Total Penjualan & $:$ & Rp. 3000 X 60 Bks $=$ Rp. 180.000 \\
\hline Laba Kotor & $:$ & Rp. $180.000-$ Rp. 115.000 \\
\hline Laba Bersih & $:$ & Rp. 65.000 \\
\hline
\end{tabular}

Proses selanjutnya setelah produksi kripik ampas tahu adalah proses packing. Packing atau pengemasan merupakan salah satu strategi untuk menarik minat beli masyarakat. Packing yang menarik akan membuat masyarakat tertarik untuk membeli produk yang ditawarkan. Kunci utama untuk membuat sebuah desain kemasan yang baik adalah kemasan tersebut harus sederhana, fungsional, dan menciptakan respons emosional positif yang secara tidak langsung "berkata", "Belilah saya." Kemasan harus dapat menarik perhatian secara visual, emosional dan rasional. Sebuah desain kemasan yang bagus memberikan sebuah nilai 
tambah terhadap produk yang dikemasnya. ${ }^{6}$ Berikut disajikan bentuk pengemasan Keripik Ampas Tahu di Desa Bringinan.

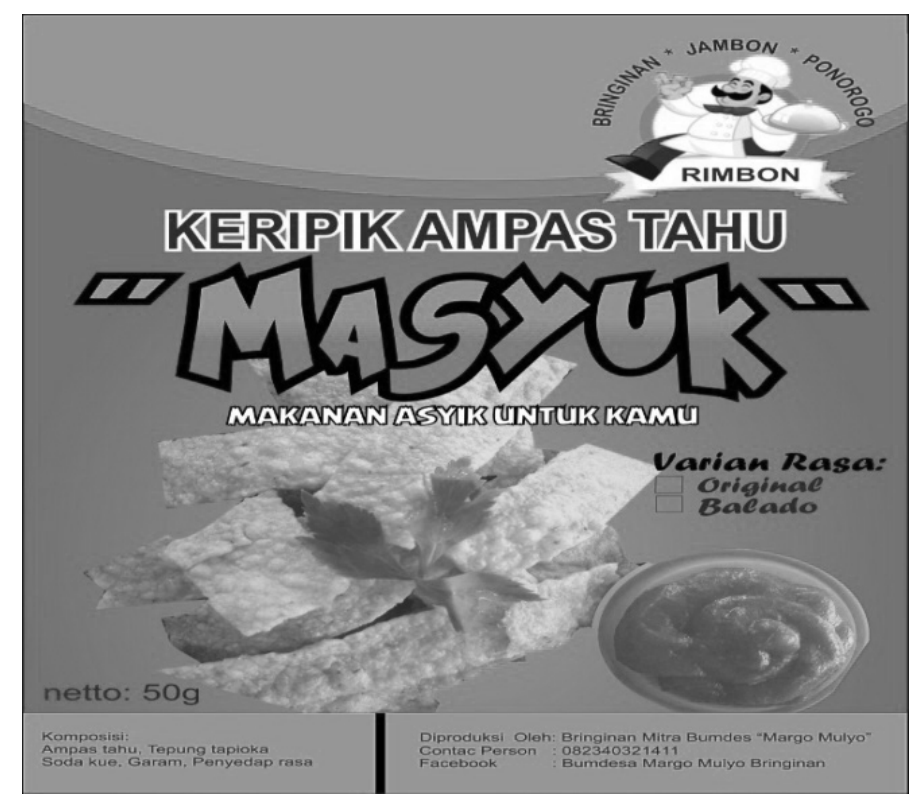

Gambar 6. Contoh Kemasan Keripik Ampas Tahu

Pada kegiatan pendampingan ini, sebagai langkah awal, fasilitator menyediakan desain kemasan dengan warna yang cerah, tidak terlalu banyak kata-kata (sederhana), dan menyajikan gambar kripik ampas tahu yang menarik untuk di makan. Berikut gambar kemasan yang disediakan oleh fasilitator.

Selain seperti yang ditunjukkan pada gambar tersebut, fasilitator juga mensosialisasikan pemanfaatan packing dengan bahan plastik yang sering disebut stand pouch dengan pertimbangan kualitas kripik ampas tahu tetap terjaga kerenyahannya. Stand pouch sangat rapat sehingga kripik ampas tahu tidak mudah lembab.

Selain pengemasan yang menarik, masyarakat juga memerlukan pendampingan tentang pemasaran. Setelah produk diproduksi dan dikemas maka langkah selanjutnya adalah pemasaran. Home industry di Desa Bringinan ini dibawah tanggung jawab kepala desa, sehingga untuk pemasarannya juga terkait dengan komponen yang ada di Desa Bringinan, yakni BUMDES. BUMDES di Desa Bringinan sering disebut Margo Mulyo atau lebih terkenal dengan nama Bringinan Mart. Selain pemasaran melalui Bringinan Mart fasilitator

6 Christine Suharto Cenadi, "Peranan Desain Kemasan dalam Dunia Pemasaran," Nirmana, Vol. 2, no. 21 (2000): 92. 
juga mensosialisasikan pemasaran secara online. Pemasaran online ditujukan untuk pemuda yang ada di Desa Bringinan, sehingga tidak hanya ibu-ibu PKK yang terlibat aktif dalam proyek home industry ini, malainkan pemuda juga.

Proses pelaksanaan program tidak hanya selesai pada proses sosialisasi. Fasilitator tetap akan mendampingi program tersebut sampai home industry benar-benar mapan dari segi pelaksanaan produksi, pengemasan, dan pemasaran. Selain dampingan dari fasilitator, program ini juga mendapat dukungan penuh dari Bapak Lurah Desa Bringinan sehingga keperluan-keperluan yang diperlukan masyarakat dapat diusahakan untuk dipenuhi dengan dukungan jaringan Bapak Lurah Barno yang luas.

Kegiatan perekonomian daerah seperti di Desa Bringinan selama ini sebagian besar ditunjang oleh usaha yang bersumber pada usaha mikro kecil yang dijalankna oleh masyarakat. Hal ini terbukti dengan banyaknya terdapat usaha-usaha kecil sebagai pilar ekonomi kerakyatan yang dapat menjadi perekonomian daerah, misalnya pabrik tahu yang dijalankan secara perorangan.

Makanan khas suatu daerah merupakan suatu ikon yang menjadi identitas suatu daerah tersebut. Ssaat ini usaha suatu industry makanan menjadi suatu perubahan dalam menentukan khas suatu desa tersebut. Perubahan gaya hidup, selera, dan cara dalam menikmati atau mengonsumsi makanan oleh masyarakat membuat para produsen makanan atau kuliner mencari inovasi baru dalam mengolah makanan. Salah satu yang diangkat dalam kegiatan ini adalah membuat inovasi makanan dari ampas tahu yakni keripik ampas tahu

Pada pameran one village one product yang digelar oleh Kecamatan Jambon, Desa Bringinan menjadikan keripik ampas tahu sebagai salah satu produk khas dan produk anadalan yang menjadi penciri khusus makanan khas Desa Bringinan. Dalam hal ini kualitas produk merupakan faktor yang dipertimbangkan konsumen untuk memutuskan membeli atau tidak produk yang disediakan. Kualitas produk ini bisa mencapai stabilitas pasar dengan harga yang dibilang terjangkau. Mulai dari cita rasa, kebersihan, dan bahkan pada packing yang menarik, sasaran dan strategi pemasaran. Penjualan kripik ampas tahu terus dipantau oleh Bapak Lurah Desa Bringinan. Sampai saat ini penjualan kripik ampas tahu yang berjalan adalah penjualan melalui BUMDES dan secara individu dijual di pasar.

Pembentukan home industry di masing-masing dusun di Desa Jambon, berdampak pada pengurangan jumlah pengangguran di Desa jambon. Pengurangan pengangguan terutama terjadi di kalangan ibu-ibu PKK. Pada awalnya ibu-ibu yang tidak bekerja berkumpul hanya ngrumpi sekarang menjadi lebih bermanfaat karena menghasilkan produk makanan yang bernilai jual. Selain itu, kegiatan ini juga menjadi salah satu cara alternatif untuk mengurangi jumlah TKW di Desa Jambon. Karena meskipun tingkat perekonomian meningkat, adanya TKW juga menyebabkan terjadinya beberapa masalah, salah satunya adalah perceraian. Meskipun pengaruhnya terhadap perceraian tidak signifikan, tatapi ditemukan beberapa 
kasus perceraian akibat adanya TKW. ${ }^{7}$

Dampak adanya home industry keripik ampas tahu ini sebenarnya juga dapat meningkatkan perekonomian msyarakat Desa Bringinan, khususnya ibu-ibu PKK. Ibu-ibu PKK yang semula tidak memiliki penghasilan dapat menciptakan lapangan pekerjaan sendiri dan menambah penghasilan untuk keluarganya. Jadi pemasukan tidak hanya dari kepala rumah tangga yaitu suami.

Dampak yang terakhir adalah pemanfaatan limbah menjadi bernilai jual yang lebih tinggi dibandingkan dijual tanpa pengolahan. Masyarakat dapat menciptakan inovasi baru dalam pengolahan limbah ampas tahu menjadi makanan yang berdaya jual tinggi. Inovasiinovasi ini akan menjadi ciri khas masyarakat Desa Bringinan.

\section{KESIMPULAN}

Kegiatan-kegiatan yang telah dilakukan di Desa Bringinan, yakni terkait dengan produksi, pengemasan, dan pemasaran keripik ampas tahu hasil pengolahan limbah tahu harus mempunyai tindak lanjut supaya kegiatan tersebut dapat berjalan secara terus-menerus dan berkesinambungan. Diharapkan program ini akan meningkatkan perekonomian masyarakat Desa Bringinan, baik ibu-ibu PKK, pemuda, dan seuruh masyarakat Desa Bringinan.

Tindak lanjut kegiatan yang sudah berjalan tersebu meliputi beberapa hal. Pertama, koordinasi dan komunikasi yang berkelanjutan dengan warga Bringinan untuk menjalin silaturrahmi dan memberi pengarahan terhadap kegiatan yang telah berjalan. Kedua, melakukan controlling dan monitoring (pemantuan) terhadap pengembangan aset Desa Bringinan yang telah dikembangkan menjadi produk inovatif yang berdaya jual tinggi. Ketiga, melakukan evaluasi dari setiap kegiatan untuk mengetahui manfaat dan kekurangannya bagi masyarakat, sehingga ada rekomendasi untuk tetap dilanjutkan atau dihentikan. Sampai artikel ini ditulis keripik ampas tahu ini sudah mendapatkan Sertifikat Produksi Pangan Industri Rumah Tangga dari Dinas Kesehatan Kabupaten Ponorogo pada tanggal 15 April 2020.

\section{DAFTAR PUSTAKA}

“Ampas Tahu Sebagai Pakan Ternak | peternakankita.com.” Diakses 19 November 2019. http:/ /www.peternakankita.com/ampas-tahu-sebagai-pakan-ternak/.

Auliana, Rizqie. (2017). "Pengolahan Limbah Tahu menjadi Berbagai Produk Makanan." Pertemuan dipresentasikan pada Pertemuan Dasa Wisma, Dusun Ngasem Sindumartani, Kecamatan Ngemplak, Sleman, Yogyakarta.

Cenadi, Christine Suharto. (2000). "Peranan Desain Kemasan dalam Dunia Pemasaran,"

Eli Karlina, Muhammad Arif, dan Sodikin, "Pengaruh Bekerja di Luar Negeri terhadap Tingkat Ekonomi dan Perceraian,” Sosio Didaktika, Vol. 4, no. 1 (2017): 60. 
Nirmana, Vol. 2, no. 21, 92-103.

Derau, Christopher. "Pembaru dan Kekuatan Lokal untuk Pembangunan," Australian Community Development and Civil Society Strenghtening Scheme (ACCESS) Tahap II, Agustus 2013.

Eta Yuni Lestari, Mike Meida Diningrum, dan Lukman Ibnu Haqiqi. (2019). "Pengembangan Nilai Tambah Ampas Tahu Bernilai Ekonomi melalui Pemberdayaan Masyarakat Desa Dadirejo Pati," ABDIMAS: Jurnal Pengabdian Masyarakat, 23, no. 2, $175-81$.

Karlina, Eli, Muhammad Arif, dan Sodikin. (2017). "Pengaruh Bekerja di Luar Negeri terhadap Tingkat Ekonomi dan Perceraian," Sosio Didaktika, Vol. 4, no. 1, 54-60.

Lembaga Penelitian dan Pengabdian kepada Masyarakat (LPPM) IAIN Ponorogo. (2019). Panduan KPM ABCD LAIN Ponorogo. Ponorogo: Lembaga Penelitian dan Pengabdian kepada Masyarakat (LPPM) IAIN Ponorogo.

Merkuria Karyantina, dan Kapti Rahayu K. (2017). "Pelatihan Pembuatan Stik dan Kerupuk Ampas Tahu di Perumnas Mojosongo," ADIWIDYA, 1, no. 1, 42-50. 